\title{
Recent Advances in the Chemistry of Gold(I) Complexes with C-, N- and S-Donor Ligands Part I: Alkynyl, Amino, Imino and Nitrido Derivatives
}

\author{
José Vicente, ${ }^{*} M$ Teresa Chicote, M Dolores Abrisqueta, Pablo González-Herrero, and Rita Guerrero \\ Grupo de Química Organometálica, Departamento de Química Inorgánica, Facultad de Química, Universidad de Murcia, \\ Apartado 4021, Murcia, 30071 Spain
}

In this paper, and in Part II to be published later, we give an account of the chemistry of gold(I) complexes with $\mathrm{C}$-, $\mathrm{N}$-, and S-donor ligands. In this first part, the synthesis of gold(I) complexes with alkynyl and $\mathrm{N}$-donor ligands is reported.

\section{INTRODUCTION}

Gold(I) complexes are interesting from both basic and applied points of view (1-5). Thus, many gold(I) complexes show Au...Au interactions that are weaker than normal covalent bonds but stronger than van der Waals forces. These interactions are called aurophilic because it was in gold complexes that they were first found $(6,7)$. Such interactions determine the supramolecular structure of many gold(I) complexes as well as the formation of rare hypercoordinate complexes (8-12). Much of the present basic research devoted to gold(I) complexes is aimed at the synthesis and structural characterization of new complexes (particularly hypercoordinate) in order to better understand the aurophilic interaction.

Because gold(I) has a high preference for S- and Pdonor ligands, ie soft ligands, to give linear twocoordinate complexes, the synthesis of complexes with $\mathrm{N}$ - and O-donor ligands or with coordination numbers three and four (13) are other areas of fundamental importance.

The search for gold(I) complexes with potential applications is also an important research area (5). In this respect, the synthesis of complexes with S-donor ligands is probably one of the more active areas because it is well known that such complexes find important applications for the treatment of rheumatoid arthritis (14-16).
However, although other potential medical applications of these complexes have been reported (16-22), as yet no gold compound has entered into clinical trials.

Some rod-like isocyanide or alkynyl-isocyanidegold(I) complexes have mesomorphic properties (23-28). In general, the usual linear coordination of gold(I) makes its complexes potentially useful metal-based liquid crystalline materials (metallomesogens) (29). In some cases, a relationship between the aurophilic interaction and potentially interesting properties has been suggested, as in the case of the solvoluminescence of some trinuclear complexes $(30,31)$ and luminescence of some alkynyl or alkynyl-isocyanidegold(I) complexes $(32,33)$. Some alkynylgold(I) complexes show non-linear optical properties $(34,35)$ and isonitrilegold(I) nitrates are effective precursors for chemical deposition of gold on iron oxide to give catalysts which efficiently oxidize carbon monoxide in air at low temperatures (36).

In the first part of this account, we report our recent results in the synthesis of alkynylgold(I) complexes containing isocyanide, carbene, halide, amine, phosphine or aryl ligands and also ammine and other $\mathrm{N}$-donor derivatives of gold(I). Only a few of these complexes display aurophilic interactions but those that do so are of unprecedented nature. In the second part of this account we will report new gold(I) complexes with sulfur containing ligands. 


\section{ALKYNYLGOLD(I) COMPLEXES}

As stated above, the rapidly growing interest in alkynyl metal complexes is based mainly on their non-linear optical, liquid-crystalline, photophysical or photochemical properties. Most alkynyl gold(I) complexes are neutral, and have the formulae $[\mathrm{Au}(\mathrm{C} \equiv \mathrm{CR})]_{\mathrm{n}}, \quad[\mathrm{Au}(\mathrm{C} \equiv \mathrm{CR})(\mathrm{L})]$ or $\left[\mathrm{Au}_{2}(\mu-\mathrm{C} \equiv \mathrm{C}) \mathrm{L}_{2}\right]$ with $\mathrm{L}=$ phosphine $(37-44)$, although a few complexes with isocyanide $(25,28,45-47)$, amine $(48,49)$, or ylide ligands (50) have also been reported.

We have prepared a wide variety of anionic and neutral alkynyl gold(I) complexes by various synthetic routes. The use of the 'acac method' (acac = acetylacetonate) based on the general reactions (1) and (2) allowed us to prepare gold(I) complexes with ylide, thiolato, phosphide, bis(diphenylphosphino) methanide or alkyl ligands (12, 51-69):

$$
\begin{gathered}
{[\mathrm{Au}(\mathrm{acac}) \mathrm{L}]+\mathrm{BH} \rightarrow[\mathrm{Au}(\mathrm{B}) \mathrm{L}]+\mathrm{acacH}} \\
\left.\left[\mathrm{Au}(\mathrm{acac})_{2}\right]^{-}+2 \mathrm{BH} \rightarrow\left[\mathrm{Au}^{(B)}\right)_{2}\right]^{-}+2 \mathrm{acacH}
\end{gathered}
$$

Thus, by reacting $\left[\mathrm{Au}(\mathrm{acac})\left(\mathrm{PPh}_{3}\right)\right]$ with the phosphonium salt $\left[\mathrm{Ph}_{3} \mathrm{PCH}_{2} \mathrm{C}(\mathrm{O}) \mathrm{Me}\right] \mathrm{ClO}_{4}$, the ylide complex $\left[\mathrm{Au}\left\{\mathrm{CH}\left(\mathrm{PPh}_{3}\right) \mathrm{C}(\mathrm{O}) \mathrm{Me}\right\}\left(\mathrm{PPh}_{3}\right)\right]$ can be obtained. The extension of this method to prepare new alkynyl gold(I) complexes, by reacting $\mathrm{PPN}\left[\mathrm{Au}(\mathrm{acac})_{2}\right]$ $\left(\mathrm{PPN}=\mathrm{N}\left(\mathrm{PPh}_{3}\right)_{2}\right)$ or $\mathrm{PPN}[\mathrm{Au}(\mathrm{acac})(\mathrm{R})]$ or $\left[\mathrm{Au}(\mathrm{acac})\left(\mathrm{PR}_{3}\right)\right]$ with terminal alkynes (see Box 1), provides further examples of its versatility $(68,70,71)$. The use of acetylene allowed the synthesis of the first family of ethynylgold(I) complexes (68). Only one well characterized ethynyl gold(I) complex had previously been reported, ie $\left[\mathrm{Au}(\mathrm{C} \equiv \mathrm{CH})\left(\mathrm{PPr}^{\mathrm{i}}{ }_{3}\right)\right](72)$.

Ligand exchange reactions between equimolar amounts of $\mathrm{PPN}\left[\mathrm{Au}(\mathrm{C} \equiv \mathrm{CH})_{2}\right](\mathbf{1})$ and $\mathrm{PPN}\left[\mathrm{AuX}_{2}\right]$ or $\left[\mathrm{Au}\left(\mathrm{PR}_{3}\right)_{2}\right] \mathrm{ClO}_{4}$ lead to ethynyl(halo)aurate(I) (4) or ethynyl(phosphine)gold(I) (5) complexes, respectively (see Box 1) $(68,71)$. The only previously reported complexes of the type $\mathbf{4}$ are the phenylethynyl derivatives obtained by reacting $[\mathrm{Au}(\mathrm{C} \equiv \mathrm{CPh})]_{\mathrm{n}}$ with a halide $(73,74)$. Complexes $\left[\mathrm{Au}(\mathrm{C} \equiv \mathrm{CR})\left(\mathrm{PR}_{3}^{\prime}\right)\right]$ analogous to $\mathbf{5}$ are among the best known alkynyl gold(I) derivatives, and they have been prepared by various methods (45, 48, 72, 75-79).

An alternative synthetic route to alkynylgold(I) complexes is the reaction of chlorogold(I) complexes with the corresponding alkyne in the presence of a base (see Box 2) (71). Although this reaction had been reported (75) to produce some neutral alkynyl(phosphine)gold(I) complexes in the presence

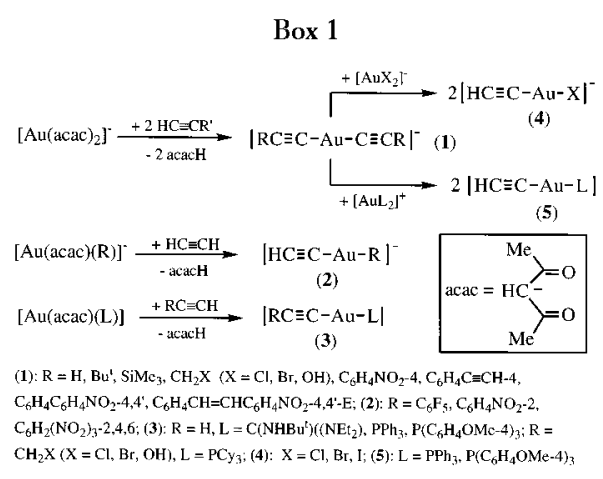

of $\mathrm{CuCl}$, we have proved that the method is more general and that $\mathrm{CuCl}$ is not needed. Diethyl or triethylamine can be used to prepare alkynyl complexes with amine $(\mathbf{6})$, phosphine $(\mathbf{7}, \mathbf{8})(71)$ or pentafluorophenyl (10) ligands (80). However, when starting from $\left[\mathrm{AuCl}\left(\mathrm{CNBu}^{t}\right)\right], \mathrm{NEt}_{3}$ must be used to produce the alkynyl(isocyanide)gold complexes (11) (Box 3) because in the presence of $\mathrm{NHEt}_{2}$, the corresponding alkynyl(carbene)gold complexes (12) form as a result of the reaction of the isocyanide ligand with the secondary amine (71). Although this is a wellknown method for the preparation of carbenegold complexes (81-86), we are not aware of the previous synthesis of any alkynyl(carbene)gold(I) complexes like 12 or 14 . The use of terminal diynes leads to dinuclear complexes with bridging dialkynyl ligands $(\mathbf{8}, \mathbf{1 3}, \mathbf{1 4}$, Boxes 2 and 3) (71). The crystal structure of $\left[\mathrm{Au}\left(\mathrm{C} \equiv \mathrm{CSiMe}_{3}\right)\left(\mathrm{CNBu}^{\mathrm{t}}\right)\right]$ shows an unprecedented tetrameric aggregate consisting of a central molecule with three others connected to it by aurophilic interactions (70).

The labile alkynyl(diethylamine)gold(I) complexes (6) (Box 2) can only be obtained from [AuClL] ( $\mathrm{L}=$ tetrahydrothiophene, tht, or $\mathrm{As}_{3} \mathrm{Ph}_{3}$ ) and can be used to prepare new alkynylgold derivatives such as $\mathbf{7}$ or $\mathbf{9}$. Complexes of the type $\mathbf{6}$ have previously been prepared by reacting $[\mathrm{Au}(\mathrm{C} \equiv \mathrm{CR})]_{\mathrm{n}}$ with amine $(48,49)$ or the alkyne with $\left[\mathrm{Au}\left(\text { amine) }{ }_{2}\right]^{+}(49)\right.$.

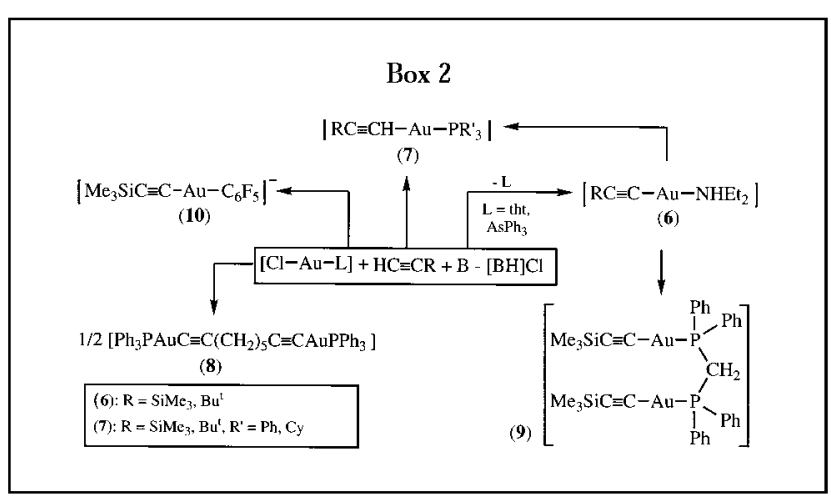




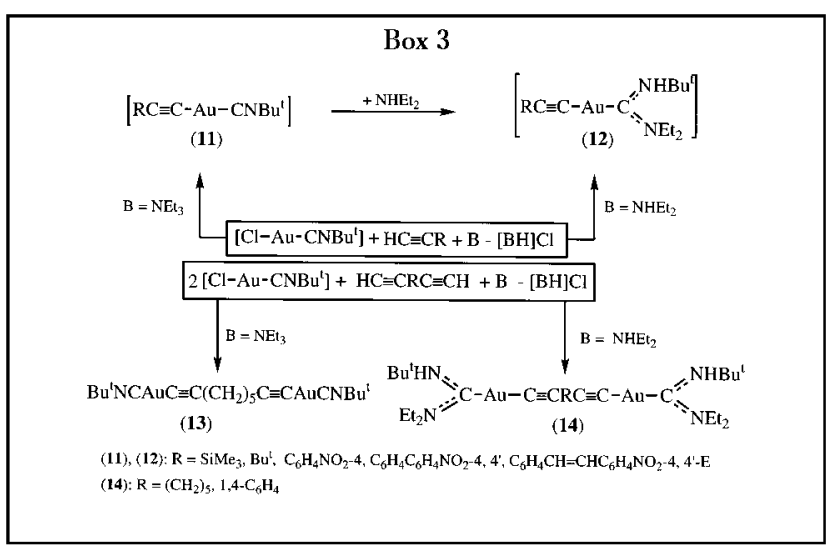

\section{GOLD(I) COMPLEXES WITH N- DONOR LIGANDS.}

Gold(I) complexes with neutral $\mathrm{N}$-donor ligands are much less common than those with $\mathrm{P}$-donor ligands due to the soft acid nature of the metal centre. We have extended the 'acac method' to the synthesis of complexes with nitrogen donor ligands. Thus, the reactions of $\left[\mathrm{Au}(\mathrm{acac})\left(\mathrm{PPh}_{3}\right)\right]$ with primary, secondary or tertiary ammonium salts $\left[\mathrm{NHRR}_{2}\right] \mathrm{X}(1: 1)$, lead to a family of cationic complexes $\left[\mathrm{Au}\left(\mathrm{PPh}_{3}\right)\left(\mathrm{NRR}_{2}\right)\right] \mathrm{X}$ (15) (see Box 4) (56). The results of these reactions depend on the nature of the solvent. Acetone can only be used in the synthesis of the tertiary amine complex (15a). In all other cases, acetone must be excluded to prevent the formation of iminogold(I) complexes (see below). Diethyl ether was chosen to ensure rapid precipitation of the complexes thus avoiding the formation of oxonium salts $\left[\left(\mathrm{Au}\left(\mathrm{PR}_{3}\right)_{3} \mathrm{O}\right]^{+}(\mathbf{1 6})\right.$ due to the presence of adventitious water. All attempts to prepare $\left[\left(\mathrm{AuPR}_{3}\right)_{2}\left(\boldsymbol{\mu}_{2}-\mathrm{NR}_{2}^{\prime}\right)\right]+\left(\mathrm{R}^{\prime}=\mathrm{Ph}, \mathrm{C}_{6} \mathrm{H}_{4} \mathrm{OMe}-4\right)$ (see Box 4 ), even using apparently dry solvents, failed and only the oxonium salts $\mathbf{1 6}$, resulting after hydrolysis, could be isolated (87).

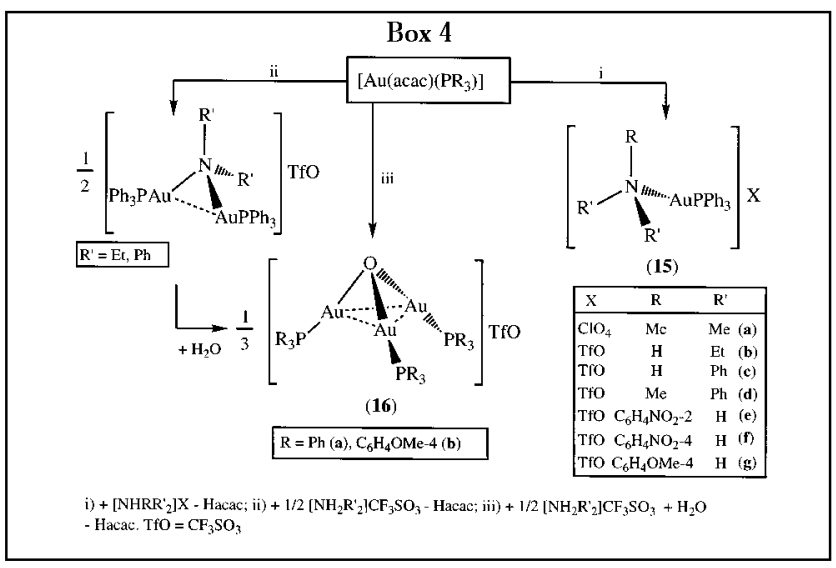

The use of $\left(\mathrm{NH}_{4}\right) \mathrm{ClO}_{4}$ allowed us to synthesize mono-, di- and tetraaurated ammonium salts (Box 5) (87). Depending on the reaction conditions, the ammino complexes $\left[\mathrm{Au}\left(\mathrm{NH}_{3}\right) \mathrm{L}_{\mathrm{ClO}}(\mathbf{1 7})\right.$, or the first amido complexes $\left[(\mathrm{AuL})_{2}\left(\mu_{2}-\mathrm{NH}_{2}\right)\right] \mathrm{ClO}_{4}$ (18)], or nitrido complexes $\left[(\mathrm{AuL})_{4}\left(\mu_{4}-\mathrm{N}\right)\right]_{\mathrm{ClO}}(\mathbf{1 9})$ can be prepared. This method of synthesis of nitrido gold(I) complexes is simpler and gives a higher yield than those previously reported $(88,89)$.

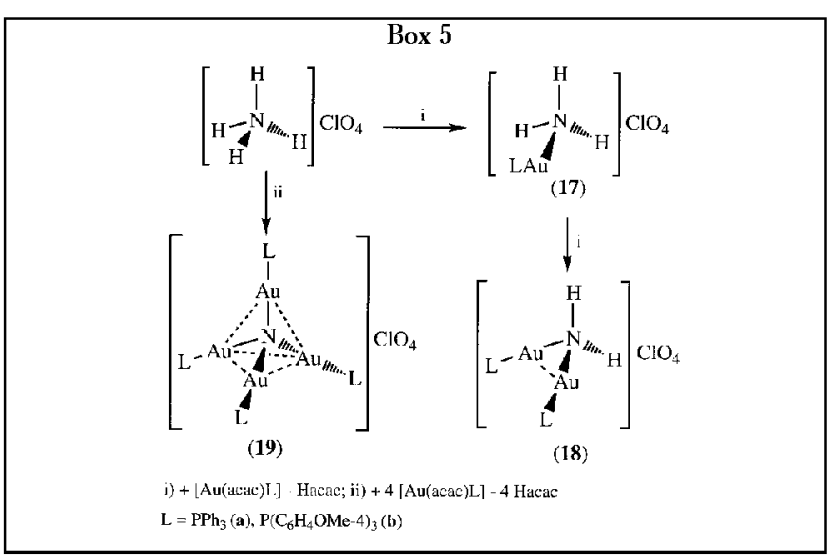

Complex $\left[\mathrm{Au}\left(\mathrm{NH}_{3}\right)_{2}\right] \mathrm{Cl}(\mathbf{2 0})$ can be easily prepared by reacting ammonia with $[\mathrm{AuCl}($ tht $)]$ (tht = tetrahydrothiophene) (see Box 6) (87). Other salts of 20 were prepared using $\left[\mathrm{Au}(\mathrm{NCPh})_{2}\right]^{+}$as the starting material (90). Our method is simpler and uses a classical starting material for the synthesis of gold complexes such as $[\mathrm{AuCl}(\mathrm{tht})](91,92)$. Different salts of $\mathbf{2 0}$ can be prepared by reacting $20 . \mathrm{Cl}$ with the appropriate silver or thallium salts. Complex 20 reacts very slowly with acetone to give the first iminogold(I) complexes $\left[\mathrm{Au}\left(\mathrm{NH}=\mathrm{CMe}_{2}\right)_{2}\right] \mathrm{X}(\mathbf{2 1} \cdot \mathrm{X})$. The crystal structure of $21 \cdot \mathrm{O}_{3} \mathrm{SCF}_{3}$ shows a polymeric chain in which aurophilic contacts along with $\mathrm{N}-\mathrm{H} \cdots \mathrm{O}$ hydrogen bonds could compensate repulsions among the cationic fragments (70). We have also prepared other imino complexes of the types $[\mathrm{Au}(\mathrm{NH}=\mathrm{CMe}) \mathrm{Cl}], \quad\left[\mathrm{Au}\left\{\mathrm{NR}=\mathrm{C}\left(\mathrm{R}^{\prime}\right) \mathrm{Me}\right\}\left(\mathrm{PR}_{3}\right)\right]^{+}$ $\left(\mathrm{R}=\mathrm{H}, \mathrm{C}_{6} \mathrm{H}_{4} \mathrm{OMe}-4 ; \mathrm{R}^{\prime}=\mathrm{Me}\right.$, Et; $\mathrm{R}^{\prime \prime}=\mathrm{Ph}, \mathrm{C}_{6} \mathrm{H}_{4} \mathrm{OMe}-$ 4), and $\left[\mathrm{Au}\left(\mathrm{NH}=\mathrm{CMe}_{2}\right) \mathrm{Cl}_{3}\right]$ (93). Related complexes $\left[\mathrm{Au}\left(\mathrm{NH}=\mathrm{CR}_{2}\right) \mathrm{Cl}\right]$ and $\left[\mathrm{Au}\left(\mathrm{NH}=\mathrm{CR}_{2}\right)\left(\mathrm{PR}_{3}\right)\right](\mathrm{R}=\mathrm{Ph}$, $\mathrm{NMe}_{2}$ ) have recently been prepared $(94,95)$.

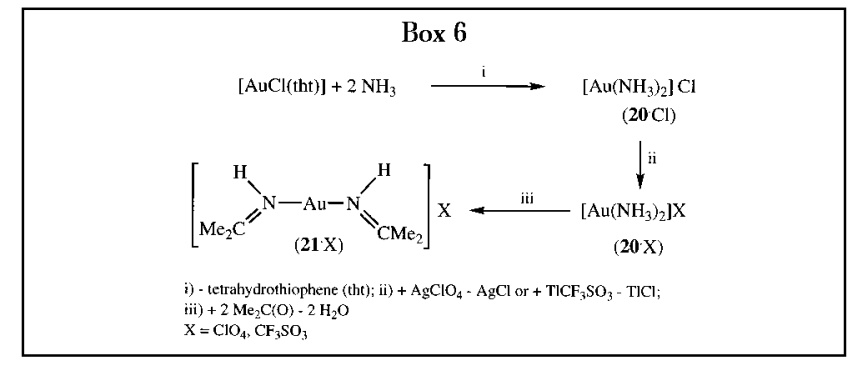




\section{CONCLUSIONS}

We have reported a number of different methods for the synthesis of gold(I) complexes. Thus, the 'acac method' allows the preparation of neutral, anionic or cationic complexes by reacting [Au(acac)L] or $\left[\mathrm{Au}(\mathrm{acac})_{2}\right]^{-}$with protic acids such as alkynes or ammonium salts. Ligand exchange reactions lead to complexes with two different ligands by reacting symmetrical complexes $\left(e g \quad\left[\mathrm{Au}(\mathrm{C} \equiv \mathrm{CH})_{2}\right]^{-}+\right.$ $\left.\left[\mathrm{AuX}_{2}\right]^{-} \rightarrow 2[\mathrm{AuX}(\mathrm{C} \equiv \mathrm{CH})]^{-}\right)$. Several methods have been applied to the synthesis of alkynyl complexes. Replacement of weakly bonded ligands, such as amines or tetrahydrothiophene, enabled the preparation of new alkynyl derivatives or complexes with ammine ligands.

\section{ACKNOWLEDGMENTS}

The authors wish to express their appreciation to Professor Peter $G$ Jones for solving the crystal structure of many of the complexes reported here and DGES (Spain) for financial support.

\section{ABOUT THE AUTHORS}

Professors María Teresa Chicote and Jose Vicente received their PhD degrees from Zaragoza University under the supervision of Professor Rafael Usón. They spent the year 1976 in Bristol University where they worked with Professor F Gordon A Stone. Since 1980 they have been at Murcia University.

Dr María Dolores Abrisqueta and Dr Pablo González Herrero received their $\mathrm{PhD}$ 's this year from Murcia University and Rita Guerrero is now studying for her $\mathrm{PhD}$. They have been working under the supervision of Professors Vicente and Chicote on the chemistry of gold(I) complexes described in this paper.

\section{REFERENCES}

1 P.D. Akrivos, H.J. Katsikis and A. Koumoutsi, Coord. Chem. Rev, 1997, 167, 95

2 K.I. Grandberg and V.P. Dyadchenko, J. Organomet. Chem., 1994, 474, 1

3 R.V. Parish, Gold Bull., 1998, 31, 14

4 R.V. Parish, Gold Butl., 1997, 30, 3

5 R.V. Parish, Gold Bull., 1997, 30, 55

6 H. Schmidbaur, Gold Bull., 1990, 23, 11

7 O. Steigelmann, P. Bissinger and H. Schmidbaur, Angew. Chem. Int. Ed. Engl., 1990, 29, 1399
8 H. Schmidbaur, Chem. Soc. Rev, 1995, 391

9 F.P. Gabbai, A. Schier, J. Riede and H. Schmidbaur, Chem. Ber, 1997, 130, 111

10 J.M. Lopez de Luzuriaga, A. Schier and H. Schmidbaur, Chem. Ber, 1997, 130, 221

11 R.E. Bachman and H. Schmidbaur, Inorg. Chem., 1996, 35, 1399

12 J. Vicente, M.T. Chicote, R. Guerrero and P.G. Jones, J. Am. Chem. Soc., 1996, 118, 699

13 M.C. Gimeno and A. Laguna, Chem. Rev, 1997,97, 511

14 S.J. Berners-Price and P.J. Sadler, Coord. Chem. Rev., 1996, 151, 1

15 S.P. Fricker, Gold Bull, 1996, 29, 53

16 S.L. Best and P.J. Sadler, Gold Bull., 1996, 29, 87

17 S.P. Fricker, Trans. Met. Chem., 1996, 21, 377

18 M. Viotte, B. Gautheron, M.M. Kubicki, I.E. Nifant'ev and S.P. Fricker, Met--Based Drugs, 1995, 2, 311

19 C.K. Mirabelli, R.K. Johnson, C.M. Sung, L. Faucette, K. Muirhead and S.T. Crooke, Cancer Res, 1985, 45, 32

20 S.Y.M. Chooi, P.H. Leung, K.Y. Sim, K.S. Tan and O.L. Kon, Tetrahedron: Asymmetry, $1994,5,49$

21 T. Okada, B.K. Patterson, S.-Q. Ye and M.E. Gurney, Virology, 1993, 192, 631

22 T.M. Simon, D.H. Kunishima, D.H. Vibert and A. Lorber, Cancer Res, 1981, 41, 94

23 R. Bayon, S. Coco, P. Espinet, C. Fernandez-Mayordomo and J.M. Martin-Alvarez, Inorg, Chem, 1997, 36, 2329

24 M. Benouazzane, S. Coco, P. Espinet and J.M. Martín-Alvarez, J. Mater. Chem., 1995, 5,441

25 P. Alejos, S. Coco and P. Espinet, New J. Chem., 1995, 19, 799

26 S. Coco, P. Espinet, S. Falagan and J.M. Martín-Alvarez, New J. Chem., 1995, 19, 959

27 T. Kaharu, R. Ishii and S. Takahashi, J. Chem. Soc, Chem. Commun., 1994, 1349

28 M.J. Irwin, G.C. Jia, N.C. Payne and R.J. Puddephatt, Organometallics, 1996, 15, 51

29 J.L. Serrano, Metallomesogens, VCH: Weinheim, Germany, 1996

30 E.Y. Fung, M.M. Olmstead, J.C. Vickery and A.L. Balch, Coord. Chem. Rev, 1998, 171,151

31 L.H. Gade, Angew. Chem., Int. Ed. Engl, 1997, 36, 1171

32 M.J. Irwin, J.J. Vittal and R.J. Puddephatt, Organometallics, 1997, 16, 3541

33 H. Xiao, K.-K. Cheung and C.-M. Che, J. Chem. Soc, Dalton Trans, 1996, 3699

34 I.R. Whittall, M.G. Humphrey, M. Samoc and B. Lutherdavies, Angew. Chem., Int. Ed. Engl, 1997, 36, 370

35 I.R. Whittall, M.G. Humphrey, S. Houbrechts, J. Maes, A. Persoons, S. Schmid and D.C.R. Hockless, J. Organomet. Chem, 1997, 544, 277

36 T.J. Mathieson, A.G. Langdon, N.B. Milestone and B.K. Nicholson, Chem. Commun., 1998,371

37 X. Hong, K.K. Cheung, C.X. Guo and C.M. Che, J. Chem. Soc., Dalton Trans, 1994 , 1867

38 V.W.W. Yam, S.W.K. Choi and K.K. Cheung, J. Chem. Soc, Dalton Trans., 1996, 3411

39 VWW. Yam and S.W.K. Choi, I. Chem. Soc, Dalton Trans, 1996, 4227

40 B.C. Tzeng, W.C. Lo, C.M. Che and S.M. Peng, Chem. Commun., 1996, 181

41 D. Li, X. Hong, C.M. Che, W.C. Lo and S.M. Peng, J. Chem. Soc, Dalton Trans. 1993, 2929

42 VWW. Yam, S.W.K. Choi and K.K. Cheung, Organometallics, 1996, 15, 1734

43 N.C. Payne, R. Ramachandran and R.J. Puddephatt, Can. J. Chem, 1995, 73, 6

44 G.C. Jia, R.J. Puddephatt, J.D. Scott and J.J. Vittal, Organometallics, 1993, 12, 3565

45 H. Xiao, Y.X. Weng, S.M. Peng and C.M. Che, J. Chem. Soc., Dalton Trans., 1996, 3155

46 G.C. Jia, N.C. Payne, J.J. Vittal and R.J. Puddephatt, Organometallics, 1993, 12, 4771 
47 G.C. Jia, R.J. Puddephatt, J.J. Vittal and N.C. Payne, Organometallics, 1993, 12, 263

48 G.E. Coates and C. Parkin, J. Chem. Soc, Chem. Commum, 1962, 1787

49 J. Yau and D.M.P. Mingos, J. Chem. Soc., Dalton Trans, 1997, 1103

50 C.J. Aguirre, M.C. Gimeno, A. Laguna, M. Laguna, J.M.L. De Luzuriaga and F. Puente, Inorg. Chim. Acta, 1993, 208, 31

51 J. Vicente, M.T. Chicote, I. Saura-Llamas and M.C. Lagunas, Chem. Commun (Cambridge), 1992,915

52 J. Vicente, M.T. Chicote and M.C. Lagunas, Inorg. Chem., 1993, 32, 3748

53 J. Vicente, M.T. Chicote and P.G. Jones, Inorg. Chem., 1993, 32, 4960

54 J. Vicente, M.T. Chicote, P. González-Herrero, P.G. Jones and B. Ahrens, Angew. Chem., Int. Ed. Engl, 1994, 33, 1852

55 J. Vicente, M.T. Chicote, P. González-Herrero and P.G. Jones, J. Chem. Soc, Dalton Trans, 1994, 3183

56 J. Vicente, M.T. Chicote, P. González-Herrero and P.G. Jones, J. Chem. Soc, Chem. Commutn, 1995,745

57 J. Vicente, M.T. Chicote and C. Rubio, Chem. Ber, 1996, 129, 327

58 E.J. Fernández, M.C. Gimeno, P.G. Jones, A. Laguna, M. Laguna and J.M. Lopez de Luzuriaga, Angew. Chem., Int. Ed. Engl, 1994, 33, 87

59 E.J. Fernández, M.C. Gimeno, P.G. Jones, A. Laguna, M. Laguna and J.M. Lopez de Luzuriaga, J. Chem. Soc, Dalton Trans., 1992, 3365

60 M.C. Gimeno, A. Laguna, M. Laguna, F. Sanmartin and P.G. Jones, Organometallics, $1993,12,3984$

61 M.C. Gimeno, A. Laguna, M. Laguna, F. Sanmartin and P.G. Jones, Organometallics, $1994,13,1538$

62 J.Vicente, M.T. Chicote, J.A. Cayuelas, J. Fernández-Baeza, P.G. Jones, G.M. Sheldrick and P. Espinet, J. Chem. Soc, Dalton Trans., 1985, 1163

63 J. Vicente, M.T. Chicote, I. Saura-Llamas, J. Turpín and J. Fernández-Baeza, J. Organomet. Chem., 1987, 333, 129

64 J. Vicente, M.T. Chicote, I. Saura-Llamas, P.G. Jones, K. Meyer-Bäse and C.F. Erdbrügger, Organometallics, 1988, 7,997

65 J. Vicente, M.T. Chicote and I. Saura-Llamas, J. Chem. Soc, Dalton Trans, 1990, 1941

66 J. Vicente, M.T. Chicote, M.C. Lagunas and P.G. Jones, J. Chem. Soc, Dalton Trans., 1991,2579

67 J. Vicente, M.T. Chicote, M.C. Lagunas and P.G. Jones, Chem. Commun. (Cambridge), 1991,1730

68 J. Vicente, M.T. Chicote and M.D. Abrisqueta, J. Chem. Soc, Dalton Trans., 1995, 497

69 J. Vicente, M.T. Chicote, R. Guerrero and P.G. Jones, J. Chem. Sox., Dalton Trans., 1995,1251
70 J. Vicente, M.-T. Chicote, M.-D. Abrisqueta, R. Guerrero and P.G. Jones, Angew. Chem., Int. Ed. Engl., 1997, 36, 1203

71 J. Vicente, M.T. Chicote, M.D. Abrisqueta and P.G. Jones, Organometallics, 1997, 16 , 5628

72 H. Werner, H. Otto, T. Ngo-Kha and C. Burschka, J. Organomet. Chem., 1984, 262, 123

73 O.M. Abu-Salah and A.R. A1-Ohaly, Inorg. Chim. Acta, 1983, 77, L159

74 O.M. Abu-Salah, A.R. Al-Ohaly, S.S. Al-Showiman and I.M. Al-Najjar, Transition Met. Chem., 1985, 10, 207

75 M.I. Bruce, E. Horn, J.G. Matisons and M.R. Snow, Aust. J. Chem., 1984, 37, 1163

76 R.J. Cross and M.F. Davidson, J. Chem. Soc, Dalton Trans, 1986, 411

77 C.M. Mitchell and F.G.A. Stone, J. Chem. Soc, Dalton Trans, 1972, 102

78 A. Johnson and R.J. Puddephatt, J. Chem. Soc, Dalton Trans, 1977, 1384

79 F. Bonati, A. Burini, B.R. Pietroni, E. Giorgini and B. Bovio, J. Organomet. Chem., 1988, 344, 119

80 J. Vicente, M.T. Chicote and M.D. Abrisqueta, unpublished results

81 J.A. McCleverty and M.M.M. Da Mota, J. Chem. Soc, Dalton Trans, 1973, 2571

82 G. Minghetti, L. Baratto and F. Bonati, J. Organomet. Chem., 1975, 102, 397

83 F. Bonati and G. Minghetti, J. Organomet. Chem., 1973, 59, 403

84 J.E. Parks and A.L. Balch, J. Organomet. Chem., 1974, 71, 453

85 R. Usón, A. Laguna, J. Vicente, J. García, B. Bergareche and P. Brun, Inorg. Chim. Acta, $1978,28,237$

86 R. Usón, A. Laguna, J. Vicente, J. Garcia and B. Bergareche, J. Organomet. Chem. $1979, \mathbf{1 7 3}, 349$

87 J. Vicente, M.T. Chicote, R. Guerrero, P.G. Jones and M.C. Ramírez de Arellano, Inorg. Chem., 1997, 36, 4438

88 K. Angermaier and H. Schmidbaur, Chem. Ber, 1995, 128, 817

89 E.G. Perevalova, E.I. Smyslova, V.P. Djadchenko, K.I. Grandberg and A.N. Nesmeyanov, Lr. Akad Nauk SSSR, Ser. Khim., 1980, 1455. Chem. Abstr. 1980, 93, 178615h

90 D.M.P. Mingos, J. Yau, S. Menzer and D.J. Williams, J. Chem. Soc, Dalton Trans. 1995,319

91 R. Usón, J. Laguna and J. Vicente, J. Chem. Soc, Chem. Commun., 1976, 353

92 R. Usón, J. Laguna and J. Vicente, J. Organomet. Chem., 1977, 131, 471

93 J. Vicente, M.T. Chicote and R. Guerrero, unpublished results

94 W. Schneider, A. Bauer, A. Schier and H. Schmidbaur, Chem. Ber, 1997, 130, 1417

95 W. Schneider, A. Bauer and H. Schmidbaur, J. Chem. Soc, Dalton Trans, 1997, 415 